\title{
Enhancing English in Ecuador: Exploring Korean English Educational Policy Innovations
}

Dinamización del Inglés en Ecuador: explorando las innovaciones en políticas educativas en inglés de Corea

Revitalização do inglês no Equador: explorando as inovações nas políticas de educação de inglês na Coréia

\section{Chriselle Domenica Espinar}

Fourth semester student a pedagogy of National and Foreign Languages, University of Guayaquil, https://orcid.org/0000-0003-1273-811X, chriselle.espinarc@ug.edu.ec

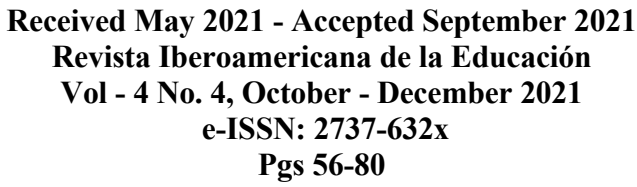

Abstract: Ecuador requires the incorporation of new educational policies that meet the needs of English today. One of the strategies required to solve this problem is to develop alongside international educational trends. This article explores the proposals in the teaching of the English language within the educational system of South Korea such as the EPIK and FSP, showing alternatives that may become applicable in the Ecuadorian context. This review is qualitative, exploratory and descriptive in scope. Information related to the needs and challenges faced by EFL contexts was recovered and organized into three main sections: (1); Specific needs of the teachinglearning of English, (2); What about teaching English in South Korea? (3); Challenges of the EFL Context. It was agreed that in Ecuador and Korea, students feel great difficulty developing productive skills (speaking / writing). Further research can take this article as a reference of the successes and challenges of EFL contexts to create more policies that can be implemented in such a way that schools, government and teachers are encouraged to take advantage of the variety of opportunities and overcome the challenges. 
Keywords: EFL context; Educational policies; English as second language; Teaching learning process.

Resumen: Ecuador requiere la incorporación de nuevas políticas educativas que se acoplen a las necesidades que demanda el inglés en la sociedad actual. Una de las estrategias requeridas para resolver este problema es desarrollarse a la par con tendencias educativas internacionales. Este artículo explora las propuestas en la enseñanza del idioma inglés dentro del sistema educativo de Corea del sur como el EPIK y FSP, mostrando alternativas que puedan llegar a ser aplicables en el contexto ecuatoriano. Esta revisión es cualitativa, de alcance exploratorio y descriptivo, se recuperó información relacionada a las necesidades y desafíos que enfrenta los contextos EFL y se organizó en tres principales apartados: (1); Necesidades específicas de la enseñanzaaprendizaje de inglés, (2); ¿Qué pasa con enseñanza de inglés en Corea del Sur?, (3); Desafíos del Contexto EFL. Se coincidió que en Ecuador y Corea los estudiantes sienten gran dificultad desarrollando habilidades productivas (speaking/writing). Otras investigaciones pueden tomar este artículo como referencia de los éxitos y desafíos de los contextos EFL para crear más políticas que puedan implementarse de tal manera que las escuelas, el gobierno y los docentes se animen a aprovechar la variedad de oportunidades y superar los desafíos.

Palabras clave: Contexto EFL; Políticas educativas; Inglés como segunda lengua; Proceso enseñanza-aprendizaje.

Resumo: O Equador requer a incorporação de novas políticas educacionais que atendam às necessidades do inglês na sociedade atual. Uma das estratégias necessárias para resolver esse problema é se desenvolver junto com as tendências educacionais internacionais. Este artigo explora as 
propostas no ensino da língua inglesa no sistema educacional da Coreia do Sul, como o EPIK e a FSP, mostrando alternativas que podem se tornar aplicáveis no contexto equatoriano. Esta revisão tem um escopo qualitativo, exploratório e descritivo, e as informações relacionadas às necessidades e desafios enfrentados pelos contextos de EFL foram recuperadas e organizadas em três seções principais: (1); Necessidades específicas do ensinoaprendizagem de Inglês, (2); Que tal ensinar inglês na Coreia do Sul?, (3); Desafios do contexto EFL. Foi acordado que no Equador e na Coréia os alunos sentem grande dificuldade em desenvolver habilidades produtivas (fala / escrita). Pesquisas futuras podem tomar este artigo como uma referência dos sucessos e desafios dos contextos de EFL para criar mais políticas que possam ser implementadas de forma que escolas, governo e professores sejam incentivados a aproveitar a variedade de oportunidades e superar os desafios.

Palavras-chave: Contexto EFL; Políticas educacionais; Inglês como segunda língua; Processo de ensino aprendizagem.

\section{INTRODUCTION}

The desire and complexity of promoting a globalized world that disseminates better communication skills, knowledge of great usefulness and interest and quality training, today is strongly occupying a transcendental role in Ecuadorian education, for which teaching and learning A second language for the development of globalization is fundamental and an inescapable fact that must be faced, since it has great relevance in the educational field as well as in the labor field and in cultural, economic and political aspects.

Especially in the field of education, it is well known that both the educational system and the advancement of societies must rise in the same direction and at the same pace, because social action and its needs are constantly changing 
and each time with better expectations, so it is inconceivable to think that schools and universities maintain the same system that is currently known Aldana-Zavala et al. (2020). Due to this, the educational system must face the permanent challenge of providing the student with a solid professional preparation, totally avoiding the exclusivity that may exist in some specific areas of education.

Particularly the teaching of English in Ecuador according to Merchan et al. (2016) emphasize that "it is one of the main concerns of Ecuadorian teachers, highlighting that the content and quality standards that govern English programs in Ecuador are not very flexible [...]" (p.116). This causes an environment of instability for teachers who want to dynamize the teachinglearning process, which in turn demands the adaptation of new evaluation models and curricular modifications that meet the quality standards required by the teaching of the English language.

It should be noted that the teaching of the English language in Ecuador is stipulated as mandatory in public schools and universities within the educational system, in addition Bernasconi \& Celis (2017) emphasize that Ecuador offers more profound reforms compared to other countries. Therefore, English teachers have been evaluated and trained, however Santos $\&$ Weathers (2015) analyze that these activities have not had the successful performance expected in the country. Thus Gordón \& Rocío (2017) suggest that "it is necessary for Ecuadorian education to reflect on itself, on its being, its work and its purposes [...]" (p.133).

Additionally, creating a positive environment of respect and tolerance within the classroom in EFL settings is an essential part of the teaching-learning process of a second language. N. E. C. Bravo \& Belen (2019) indicate that a positive climate makes the learner feel the support of the teacher, while being concerned about their learning needs and enhancing the teacher-student 
relationship, their motivation and teamwork. Likewise, Jarrín \& Kim (2019) argue that it has an effect on their autonomy, critical thinking and student motivation. In this way, the teacher becomes a designer of their ways of imparting knowledge to reach all the learning objectives (Rea \& Román, 2019).

On the other hand, Vasquez-Martinez et al. (2018) explains that the incorporation of educational policies and other complementary policies is required to be able to overcome the difficulties they are currently facing. Therefore, one of the strategies required to overcome these difficulties is to develop alongside international educational trends. Thus, it is understood that it is necessary to integrate new methodological alternatives and adapt strategies that promote a dynamic teaching and learning process to improve the quality of English teaching in Ecuador. Given that when wanting to perform in the international framework, low English proficiency is usually a problem in students in the Ecuadorian context (Villao, 2016).

Contemplating the need to know new innovative proposals that can be coupled to the quality standards currently required by the teaching of the English language, the objectives of this review article are; identify the specific needs of the teaching-learning of English, explore the different scientific studies in the Korean educational system in English in order to publicize proposals that improved the quality of language teaching and also intends to propose alternatives that streamline the process language teaching in Ecuador. However, it is important to note that the position of this article is exploratory and reflective of the different innovative proposals that have been made in the teaching of the English language within the educational system of a nonEnglish-speaking country such as South Korea and thus know alternatives that may become applicable in the Ecuadorian context. 


\section{MATERIALS AND METHODS}

In this research, a bibliographic review was carried out with a qualitative, exploratory and descriptive approach regarding the different scientific productions directed towards the teaching- learning process of the English language in EFL environments, as well as, reports, case studies and articles as primary source of information.

For this bibliographic review, a search was carried out in the Eric, Redalyc, Scielo and REDIB databases focused on documents of scientific production in education, particularly in foreign language with a mention in English in the national and international context, carried out by universities and institutions in relation to improve dynamization in the teaching of English as a foreign language.

Due to the fact that more research and studies published in the English language were found, it was considered convenient to carry out the search for the information with the key words essentially in this language and then in Spanish. Subsequently, the reports, case studies, comparative studies and scientific articles were compiled by means of the following equations; "Korea" AND "English Education" and "EFL context" AND "Ecuador" without a date limit. Later, the thesaurus and main descriptors were modified by synonyms to make the search for significant results more precise.

Finally, the bibliographic references found within the most relevant scientific articles for this section were used with the aim of rescuing remarkable and essential information directed to the subject that has been carried out in this review. These references were retrieved from the articles obtained in the ERIC databases.

In the search for the information, documents that had studies and research carried out mainly in the educational field within the teaching of a foreign language in both South Korea and Ecuador were included, in addition, studies 
carried out in Colombia and Mexico were considered, as well as they correspond to improving the quality of teaching the English language. On the other hand, in terms of scientific articles and case studies, the inclusion criteria of these studies were corresponding to the level of schools or universities, in addition to including practical proposals to stimulate the teaching of English. Similarly, research and studies were included that in their conclusions contributed with activities to stimulate the teaching-learning process of English within the classroom.

The main exclusion criterion was that the articles found did not contain information regarding; foreign language education, improvement of English language practices, active second language learning, activities inside and outside of class and English as a second language.

Data extraction:

Subsequent to the initial search, approximately 262 results were obtained, of which 211 were excluded that did not contribute significantly, nor did they contain the information related to the research of this review article. 7 case studies, 3 comparative studies, 1 book, 2 Reports and 38 scientific articles were selected. For selection and subsequent extraction, the summaries, keywords and corresponding titles of each document were briefly examined, in the same way, it was considered convenient to read certain articles that revealed information derived from the subject of this review in order to verify whether their content was substantial to mention or not, with the purpose of adding or discarding it. For the easy management and organization of the bibliographic references of this review article, the Mendeley bibliographic manager was used.

In the data collection and analysis of the 51 studies obtained and reviewed for this article, information was recovered regarding the needs of English today, the Korean educational system in English, the challenges faced by the EFL 
contexts and organized all the information in three main sections: first; Specific needs of the teaching-learning of English, second; What about teaching the English language in South Korea? Which in turn of subdivided, third; Challenges of the EFL Context.

\section{RESULTS}

\section{Specific needs of teaching and learning English.}

Communication and international relations have increased over time in recent decades, due to this the need to develop skills in the English language as the most important way to globalization and in turn to modernization is felt in non-native English speaking countries from all over the world. Consequently, to this demand, the educational systems of all these countries where the mother tongue is not English, including Ecuador, have placed a high priority on both the teaching and learning of English.

Regarding this growing need to improve communication skills in English by countries in the context, EFL Aliakbari \& Gheitasi (2014) point out that the importance of English as a foreign language has been unquestionably beneficial, since governments and their respective educational systems for their part, they have reflected and reconsidered their language teaching programs in order to meet the needs that it currently demands.

In our context, it is necessary to emphasize the importance of having a standardized English curriculum that conforms to the standards in Ecuador to train quality teachers. This is why public and private institutions where the English language is taught require highly qualified English teachers, however most of these institutions point out that the main problem occurs when hiring educators, because they have an extremely low command of English and with few methodologies to teach the language to students in their classes even after they have graduated as English teachers (Serrano et al., 2015). It is thus 
evident that another present need is to develop programs that evaluate teachers in the performance of the language and train them so that they can function better in their classes and with better teaching methodologies. On the other hand, Carless (2006) emphasizes that from the perspective of L2 teachers, they know very well what the needs of their students are and the frequent difficulties they currently face as teachers and relate it to the syllabus and the didactic material that is used. This explains how the little flexibility of the syllabus and textbooks with information not updated to the standards that are required, can negatively affect the dynamization of the teaching of the language and the methodology of the teacher. In this vein, Toro et al. (2019) state in this regard emphasizing that to bring the teaching-learning process to success, different factors are required, ranging from the design of a good teaching plan to being flexible in the implementation of strategies that are required within the classroom.

Consequently, other studies determined that students stated that they did not have enough opportunities to speak English within or outside of class and when they were given the opportunity to communicate and exchange information in English, in written or spoken form, they showed great difficulty. in doing so, which caused negative reactions in their motivation to learn the language (Chamba et al., 2019; Shahini \& Shahamirian, 2017). For this reason, teacher support, student.

autonomy, effort to learn new vocabulary and motivation are the main factors that are needed in learning a language. In other words, Bravo et al. (2017) strongly argue that motivated students can retain much more information and in the long term, so it is necessary to see motivation as a primary factor that produces interest in learning a second language.

Likewise, new technologies cannot be excluded since they play a fairly important role in the quality and dynamism of the teaching of the English 
language. Although this idea is clear and the implementation of technology in teaching is nothing new, it represents a constant challenge, especially when it comes to integrating them into the class. Solano et al. (2017) state that, in certain developing countries such as Ecuador, even the use of technology for the teaching-learning process should be more exploited.

As can be seen in this section, English currently requires many specific needs to stimulate the teaching-learning process, of which the following can be considered primarily; Institutional support for teachers, motivation and autonomy in the student and the integration of technology in the education of a second language.

\section{What about teaching the English language in South Korea?}

It should be mentioned that South Korea has had a long journey in teaching this language, which has not been easy but whose vision has always been to improve and promote English education within the country. Chang (2009) analyzed that the history of English education in Korea is divided into two important periods, in conjunction with historical events in Korea: The Choson Dynasty Period and Japanese Imperialism Period.

\section{Choson dynasty period}

During this first period, English was brought to Korea with Christianity, it was considered as a symbol of equality and democracy to end the prevailing feudal class in the Choson dynasty (Lee, 1999; Sung, 2002 cited in Shin, 2007). However, Chang categorized this period into two groups of institutions in which English was taught to Koreans, these were public institutes and missionary schools (Chang, 2009). In addition, in this same study it was clarified that the objective of the public Institutes was to instruct Korean translators in other foreign languages, in this case English with the Direct Method, since they began to have diplomatic relations with other countries, while the Missionary schools had an impact on modernization in this period, 
not only in the English language, but also in the entire Korean society in this way English was taught with the bible as a textbook Chang (2009).

\section{Japanese imperialism period}

In this period Japan enforced cultural acceptance tactics including teaching English in Japanese to Koreans. Regarding this period, Yang (2017) explains that the Japanese took refuge in the fact that their cultural domination over Korea was a sacred duty to achieve modernization. Although English was taught, during this period it was very scarce as languages other than Japanese were canceled or banned (Sung, 2002 cited in Shin, 2007).

As can be seen in these studies for a long time there was a very low deficit of the English language, however Park \& Watson (2011) speak in their study arguing that only a few decades later, Korea now faces different challenges on this path to justice. Similarly, currently Korea has overcome different challenges in the education of English that were imposed throughout its history. For example, in Korea, the Ministry of Education inserted the policy of 세계화 (segyehwa), which is the Korean term for globalization, with the purpose of evolving from an English curriculum with instructions in traditional grammar to a communicative one (Shin, 2007). In other words, the teaching of English in Korea has shifted to focus on fluency over grammatical accuracy.

By virtue of this, Schenck (2013) mentions that, in contemporary South Korean society, culture is strongly fixed together with the expansion and growth of the command of English as the main human resource. Similarly, Jahng (2011) expresses that, considering the increase and the great position that English occupies nationally and worldwide, South Korea perceives education in English as the surest way to achieve rapid progress in education social class. Therefore, at first, education in English should be a basic human right and not a privilege (Jambor, 2012). Consequently, in South Korea it is 
openly considered that among the countries in which English is not spoken, those that promote its use are richer than other nations.

Since English education has had a great impact in almost every respect in Korean society, Choi et al. (2019) in their study highlights that for Koreans achieving a high score in English tests is an inevitable and necessary fact. This is how proficiency in this language has been the main focus for the Ministry of Education in this country. For this reason, Jeong (2020) reveals that the Korean government reformed the educational system, these reforms included vocational programs, study plans, some teacher policies, looking beyond and not only providing standardized instructions.

Jo (2008) points out that the government carried out a pilot plan from 2006 to 2007 with the aim of integrating English education at an early age, for this reason the Ministry of Education proposed the introduction of English in 1st grade. However, according to Kim et al. (2018) the national curriculum indicates that education in English begins to be taught from the 3rd grade of primary education with around 2 to 3 hours during the week. The desire to integrate early English education in Korea is because children's English skills are often related to success in their lives. In turn, the desire to improve children's English led to updating the textbooks. According to Yuasa (2010) each lesson in the English books has: "Look and Listen, Listen and Repeat, Let's Play, Let's Chant, Look and Speak, Let's Sing" (p.149). Thus, these themes in the lessons are associated with the daily lives of children.

When it comes to secondary and higher education, English education is even more demanding in South Korea and the reason why the government has constantly struggled with this educational demand. According to the study carried out by Megan I. Beard (2018) indicates that having a high command of English is not only considered when students want to obtain higher education, but also when publishing articles in English by university students. 
While it is true that these measures are necessary to qualify at elite universities in Korea, these demands have caused a great deal of stress on Korean students. As a result of these facts, the Korean government has integrated programs such as the EPIK (English Program in Korea) to improve the quality of English in the country and FSP (Free Semester Program) to alleviate the stress of students in demanded subjects as a requirement to enter the university.

\section{EPIK (English Program in Korea)}

According to Ahn et al. (1998) the English program in Korea was launched in 1995 with 856 teachers teaching in secondary schools in the country. The objective of this program is to strengthen education in foreign languages and at the same time reinforce a globalized education (EPIK, 2011). In addition, two studies agree that the program was developed to integrate native English teachers from the following countries: Australia, Canada, Ireland, New Zealand, the United Kingdom, the United States and South Africa, in the same way the main eligibility requirements are: have obtained a bachelor's degree, good physical and mental health, high English proficiency and adaptability (Jeon, 2009; A. Schenck, 2020). Additionally, Jeon (2009) mentions that the salary will depend on both the location of the school and the term of the contract and this ranges from US \$ 1,900 to US \$ 3,000 per month.

The EPIK is also beneficial for Korean English teachers, since it is a program in which, according to Wang \& Lin (2013), native English language teachers have two great duties: to jointly carry out the teaching process with local teachers and to help them to improve your skills in class. In this sense, native English teachers also have a support system that includes a Korean assistant teacher (Oh \& Nussli, 2014). In this way, Carless (2006) indicates in their results that Korean English teachers improve their communication methods and skills in the language, and also highlights the importance of the presence 
of the Korean teacher in the class, since it maintains the good behavior of the students.

\section{FSP (Free Semester Program)}

The FSP was targeted at all Korean high schools since 2016, after having gone through a three-year period as a pilot program across the country (Jung et al., 2020). This is how this program allows students to explore their future career options, it is also responsible for providing them with the essential academic skills so that they can be admitted to universities. The program covers: Mathematics, English, Chinese, science, among others (Ministry of Education). Tan (2019) mentioned that the FSP focuses on a happy education, since the university entrance exams put great pressure on Korean students. These studies thus indicate that the FSP, for its part, has also contributed to improving the learning of English and reducing a little the stress felt by students due to the compulsory command of this language for admission to the country's universities.

\section{Challenges of the EFL Context}

During the teaching-learning process in the EFL context, not only in Korea but also in Ecuador, students may feel pressure, demotivation and stress, due to the current demands of learning English and it is normally expected that they be able to cope with these feelings so that they can understand and study the language successfully. In the case of Korea, teachers tend to integrate different activities, not just those that are related to learning (Kim et al., 2018). It is well known that there is no single effective way to achieve the goal of enhancing and improving the teaching of English in EFL contexts. Therefore, it is understood that this process should not be static. Lee (2012) argues that the English language teaching process has to be carried out actively, so that the development of the student's communication and comprehension skills is continuous in participation within or outside of class. However, despite the 
fact that teachers maintain their efforts to make this participation active in EFL settings, Viáfara (2011) in her research argues that, the interaction of students in English within the classroom continues to represent a great challenge for teachers.

K. Jeong (2017) expresses that it is not easy to motivate students to develop their English skills inside EFL environments. In Ecuador, for example, according to the study by Ochoa et al. (2016) highlights that an attempt was made to solve this problem by integrating activities such as: group work, dynamics and role plays, which subsequently obtained positive responses in the motivation of the students. On the other hand, in South Korea, faced with this situation, it is considered that it can be especially useful for the teacher to make the student perceive that he has made progress, through interesting but at the same time challenging activities at the correct level. way the student will increase his confidence (N. Choi et al., 2019).

From this order of ideas, the teacher in the EFL environment must at all times bring out her virtues, be patient, understanding and above all tolerant. This great importance stems from the study carried out by Greenier \& Whitehead (2016) where they highlight EFL teachers as cultural ambassadors, given that they represent a role model of how society should treat other people who are culturally and linguistically different from them. Teachers at EFL must also possess critical thinking to adjust and perfect their own learning in teaching a second language, thus favoring their practice as a teacher in their future classroom (Saiful \& Triyono, 2018).

As a result, a recent study reveals that Ecuadorian educational policy knows well what it faces in classrooms, heterogeneity and great diversity, which makes it challenging to reach each of the students (Hernández-Chérrez \& Hidalgo-Camacho, Cynthia Soledad Carrera-Martínez, 2020). For this 
reason, teachers at the EFL must consider different learning styles and adjust their plans in the best way.

However, this same situation is not the same for South Korea, some teachers expressed that the teaching policies for the most part are not so relevant to the needs that their students actually demand (T. Choi, 2017). Consequently, productive English skills for Korean students are now a great challenge. According to Babakhouya (2019), it indicates that speaking and writing skills in a foreign language represent great anxiety for students. Similarly, it is recognized that it is also a challenge for Ecuadorian teachers to develop these skills, especially speaking, since for Toro et al. (2019) is "one of the most difficult skills to develop in students [...]" (p.102). Thus, Salazar Lugo et al. (2016) resolves that by constantly encouraging students and developing their confidence in a dynamic way in oral practice, they will be able to function better in communicative competence.

The studies presented previously revealed the specific needs in the teaching of the English language, considering mainly EFL environments, that is, countries where English is taught as a second language, in addition to Ecuador and South Korea, research carried out in Colombia and Mexico. In the same way, they highlighted what were the constant challenges in these environments. Subsequently, studies in the innovative English educational policies in South Korea were explored as an example of an EFL environment and showed alternatives to overcome these challenges.

As mentioned in the section on specific teaching-learning needs in the English language, the studies agreed that these three main aspects should be considered: Motivation and autonomy in the student, institutional support for teachers, and the integration of the technology in second language education. In Ecuador, studies indicated that the integration of new educational policies is required, programs that meet the needs of English learning today and have 
a standardized English curriculum. For this reason, South Korea exemplified programs that turned out to be successful for improving English, such as the EPIK to improve English skills within the country and FSP to reduce the stress of students in the subjects necessary for admission to the universities. It was demonstrated in both Ecuador and South Korea that they have implemented strategies and activities such as: role play, teamwork and challenging activities to stimulate the teaching of English within the classrooms, however, it remains a challenge for these two countries that students develop in English outside of them, since in EFL environments the classroom is still usually the only place where students can practice English (K. Jeong, 2017).

Along the same lines, it was discovered that students feel great anxiety developing productive skills such as speaking and writing, in the case of South Korea a study showed that even these two skills still need to be improved, while in Ecuador one of the most difficult skills to develop is speaking.

The studies also agreed that it is essential that educational policies in EFL settings are coupled to the true needs of students depending on each of their context, keeping in mind that in Ecuador teachers face students with different cultural backgrounds and in different ways. South Korea with some very rigid and inflexible educational policies.

An observation is made in the role of the teacher, where he is placed as a cultural ambassador (Greenier \& Whitehead, 2016). He is not only expected to be a guide, but also a creative person, critical thinking and above all tolerant when it comes to teaching a second language because it involves getting to know a new culture.

The main limitation of this study is that although the success of programs such as EPIK and FSP in South Korea was proven, they were carried out in a 
different context with different needs, however, it was exemplified because South Korea is part of the EFL environments that have constantly struggled to improve English as a human resource just like Ecuador.

Therefore, it is suggested for future research to resolve whether the adaptation and adjustments of the educational policies and instruments used in the international context indicated above in this study for the educational context of English in Ecuador is sustainable.

Secondly, in Ecuador it is still limited to recognizing English as a second language, but this must confront the new concept of English as an international language, it is also suggested to carry out a systematic followup study on the changes in the EFL environment in Ecuador and the use of new technologies as they are necessary to develop English education appropriately for the globalized world.

\section{CONCLUSIONS}

Thanks to international educational trends, we can learn from new experiences and aspects of life in today's society, which can be used essentially when they are the result of reflection on other realities and contexts whose main objective is to break with traditional standards, recognizing the importance of English for development and modernization.

Although the policies used in the international context may be adjusted in the Ecuadorian context in the teaching of the English language, it will be difficult for them to be applied and bear fruit without the collaboration of teachers in this subject, especially when their training in the teaching of English. a second language is not consistent or deficient. (Hernández Hernández \& Izquierdo Sandoval, 2020). Because the quality of education cannot possibly surpass the quality of teachers 
It is concluded that in Ecuador and South Korea they have placed a high priority on teaching English trying to modify their educational policies, however, there is still a long way to go to perfect these policies and adapt them to the corresponding needs in each context. Studies in Ecuador and South Korea revealed interest in fostering an active and dynamic education, willing to implement new methodologies to help overcome these challenges within EFL environments.

With regard to dynamization within classes in EFL contexts, it was shown that different activities can be used, not only related to learning, such as: watching video, group discussions, simulations or role-playing, this helps the student's motivation to learn a second language as well as including technology in the English teaching-learning process.

The role of the teacher is another important aspect in the teaching-learning process of a second language in the EFL context, although it is mentioned that there is not only one way to get teachers to dynamize their classes, this process should not be static for any reason. Teachers should promote creative ideas and challenging tasks considering the level of their students. In the same way, it must encourage respect and tolerance since they not only represent their own culture, but also teach a linguistically different one.

Finally, although Ecuador favorably has not gone through the same unfortunate events in the history of English teaching as South Korea, Korea continues to be an example of providing rapid responses to the globalization process through which this country not only It quickly adapts to the demands of international standards, but also strategically pursues national interests by offering its citizens different ways of acquiring a high command of English. 


\section{REFERENCES}

Aguilar Gordón, F. del R. (2017). The curriculum based on integrated professional competencies in the Ecuadorian university. Revista de Estudios y Experiencias En Educación, 16(31), 129-154. https://doi.org/10.21703/rexe.2017311291528

Ahn, S.-W., Park, M.-R., \& Ono, S. (1998). A Comparative Study of the EPIK and JET Program. English Teaching, 53(3), 241-267.

Aldana-Zavala, J. J., Vallejo-Valdivieso, P. A., \& Isea-Argüelles, J. (2020). Research and learning: Challenges in Latin America towards 2030. Alteridad Revista de Educación, 16(1), 78-91. https://doi.org/10.17163/alt.v16n1.2021.06.

Aliakbari, M., \& Gheitasi, M. (2014). Exploring Teachers' Perception of the Efficacy of ELT in Iranian Public Schools and Private Language Institutes. Advances in Language and Literary Studies, 5(2), 12-18. https://doi.org/10.7575/aiac.alls.v.5n.2p.12

Babakhouya, Y. (2019). The Big Five personality factors as predictors of English language speaking anxiety : A cross-country comparison between Morocco and South Korea. Research in Comparative \& International Education, 14(4), 502-521. https://doi.org/10.1177/1745499919894792

Bernasconi, A., \& Celis, S. (2017). Higher Education Reforms: Latin America in Comparative Perspective. Education Policy Analysis Archives, 25(67), 1-15. https://doi.org/10.14507/epaa.25.3240

Bravo, J. C., Intriago, E. A., Holguín, J. V., Garzon, G. M., \& Arcia, L. O. (2017). Motivation and Autonomy in Learning English as Foreign Language : A Case Study of Ecuadorian College Students. Canadian Center of Science and Education, 10(2), 100-113. https://doi.org/10.5539/elt.v10n2p100.

Bravo, N. E. C., \& Belen, E. A. G. (2019). School coexistence in the development of meaningful learning. Edwards Deming Science and Education Technology Journal, 3(1), 50-67. https://doi.org/10.37957/ed.v3i2 
Carless, D. R. (2006). Good practices in team teaching in Japan, South Korea and Hong Kong. Science Direct, 34(3), 341-351. https://doi.org/10.1016/j.system.2006.02.001

Chamba, M., Reinoso, M., \& Rengifo, E. (2019). Authentic Materials to Foster Writing Skills in College EFL Learners. Canadian Center of Science and Education, 12(6), 112-127. https://doi.org/10.5539/elt.v12n6p112

Chang, B.-M. (2009). Korea's English Education Policy Innovations to Lead the Nation into The Globalized World. Pan-Pacific Association of Applied Linguistic, $\quad$ 13(1), 83-97 .https://eric.ed.gov/?id=EJ921027

Choi, N., No, B., Jung, S., \& Lee, S. E. (2019). What affects middle school students' english anxiety in the efl context? Evidence from south korea. Education Sciences, $9(1), \quad 2-11$. https://doi.org/10.3390/educsci9010039.

Choi, T. (2017). Hidden transcripts of teacher resistance : a case from South Korea Hidden transcripts of teacher resistance : a case from South Korea. Journal of Education Policy, 32(4), 480-502. https://doi.org/10.1080/02680939.2017.1290280

English Programme in Korea (EPIK) (2011). EPIK: English Program in Korea. The EPIK website. Retrieved from http://www.epik.go.kr/

Greenier, V. T., \& Whitehead, G. E. K. (2016). Towards a Model of Teacher Leadership in ELT : Authentic Leadership in Classroom Practice. RELC Journal, 47(1), 79-95. https://doi.org/10.1177/0033688216631203.

Hernández-Chérrez, E., \& Hidalgo-Camacho, Cynthia Soledad CarreraMartínez, V. (2020). Graphic Organizers For The Enhancement Of EFL Reading Comprehension. Chakiñan Journal of Social Sciences and Humanities, 12, 106-117. https://doi.org/10.37135/chk.002.12.07

Hernández Hernández, M., \& Izquierdo Sandoval, M. J. (2020). Curricular changes and English language teaching. Teacher perception questionnaire. Sinéctica, Revista Electrónica de Educación, 54, 1-22. https://doi.org/10.31391/s2007-7033(2020)0054-

012 
Jahng, K. E. (2011). English education for young children in South Korea: Not just a collective neurosis of english fever! Perspectives in Education, 29(2), 61-69.

Jambor, P. Z. (2012). English Language Necessity: What it means for Korea and non-English speaking countries. In Online submission. https://eric.ed.gov/?id=ED528279

Jarrín, X., \& Kim, C. (2019). Improving speaking skill using the speaking practice tool Spacedeck. Espirales Multidisciplinary Journal of Research, 3(30), 88-99. https://doi.org/10.31876/er.v3i30.619

Jeon, M. (2009). Globalization and native english speakers in english programme in korea (EPIK). Language, Culture and Curriculum, 22(3), 231-243. https://doi.org/10.1080/07908310903388933.

Jeong, E. (2020). Education Reform for the Future: A Case Study of Korea. International Journal of Education and Development Using Information and Communication Technology, 16(3), 66-81. https://search.proquest.com/scholarly-journals/education- reformfuture-case-study-korea/docview/2480824220/se-2?accountid=17242

Jeong, K. (2017). Preparing EFL student teachers with new technologies in the Korean context. Computer Assisted Language Learning, 30(6), 488509. https://doi.org/10.1080/09588221.2017.1321554

Jung, H., Eun, Y., \& Insuk, K. (2020). Exploring the alleged effect of lower academic achievement after the free semester in Korean Middle Schools. Asia Pacific Education Review, 21, 639-651. https://doi.org/10.1007/s12564-020-09641-1.

Kim, T. Y., Kim, Y., \& Kim, J. Y. (2018). A Qualitative Inquiry on EFL Learning Demotivation and Resilience: A Study of Primary and Secondary EFL Students in South Korea. Asia-

PacificEducation Researcher, 27(1), 55-64. https://doi.org/10.1007/s40299-017-0365-y.

Lee, K. Y. (2012). Teaching intercultural english learning/teaching in world englishes: Some classroom activities in South Korea. English Teaching: Practice and Critique, 11(4), 190-205.

Megan I. Beard. (2018). Language as currency: Perpetuating and contesting notions of English as power in globalized Korean contexts. Journal of Comparative and International Higher Education, 10(1), 19-25. https://eric.ed.gov/?id=EJ1233254. https://eric.ed.gov/?id=EJ1233254 
Merchan, P. F., Mieles, J. L. C., \& Obando, J. J. A. (2016). Impact of differentiated education on the teaching of English as a foreign language in Ecuador.Didasc@lia: DidácticayEducation

$7(2)$,

http://revistas.ult.edu.cu/index.php/didascalia/article/view/479

Ministry of Education [Korea]. n.d. Higher education. Reterview from: http://english.moe.go.kr/sub/info.do?m=020105\&s=english.

Ochoa, C., Cabrera, P., Quiñónez, A., Castillo, L., \& González, P. (2016). The Effect of Communicative Activities on EFL Learners ' Motivation : A Case of Students in the Amazon Region of Ecuador Efecto de actividades comunicativas en la motivación de aprendices del inglés : un caso de estudiantes en la región amazónica del Ecuador. ColombianAppliedLinguisticsJournal, 18(2), 39-48.

https://doi.org/10.14483/calj.v18n2.10018

Oh, K., \& Nussli, N. (2014). Challenging, eye-opening, and changing. U.S. teacher training in Korea: Creating experiences that will enhance global perspectives. Journal of the Scholarship of Teaching and Learning, 14(4), 67-87. https://doi.org/10.14434/v14i4.12764

Park, G. C., \& Watson, S. L. (2011). In context: Multicultural education in Korea-Lessons for American educators. Multicultural Education, 19(3), 2-6. https://eric.ed.gov/?id=EJ955928.

Rea, M. O., \& Román, J. L. S. (2019). Implementing backward design to improve students' academic performance in EFL classes. Espirales Revista Multidisciplinaria de Investigación, 3(30), 43-50. https://doi.org/10.31876/re.v3i24.422

Saiful, J. A., \& Triyono, S. (2018). EFL teachers' reflection in teaching English to EFL students of rural areas. International Journal of Language Education, 2(2), 1-13. https://doi.org/10.26858/ijole.v2i2.5637

Salazar Lugo, G., García López, R., Balderrama Trapaga, J., \& Rodríguez Torres, L. (2016). Development of English oral proficiency through open educational resources. Apertura, 8(1), 1-15.

Santos, N. M. B., \& Weathers, J. R. G. (2015). EFL in Public Schools in Mexico : Dancing. Around the Ring ? 23(1), 68-84. https://doi.org/10.19183/how.23.1.297

Schenck, A. (2020). Examining the influence of native and non-native English-speaking teachers on Korean EFL writing. Asian-Pacific 
Journal of Second and Foreign Language Education, 5(2), 2-17. https://doi.org/10.1186/s40862-020-00081-3

Schenck, A. D. (2013). Korea's "Model Minority": A Case Study of an American-Korean Bilingual Student's Challenges Learning English in South Korea. Journal of International Education and Leadership, 3(3), $1-15$.

Seongja, J. (2008). English education and teacher education in South Korea. Journal of Education for Teaching, 34(4), 371-381. https://doi.org/10.1080/02607470802401594

Serrano, M. E., Vizcaíno, C. G., Cazco, D., \& Kuhlman, N. A. (2015). Transformation: A Model for Restructuring the Preparation of English Teachers in Ecuador. Gist Education and LearninG Research Journal, 11, 103-117. https://doi.org/10.26817/16925777.289.

Shahini, G., \& Shahamirian, F. (2017). Improving English Speaking Fluency: The Role of Six Factors. Advances in Language and Literary Studies, 8(6), 100-104. https://doi.org/10.7575/aiac.alls.v.8n.6p.100

Shin, H. (2007). English Language Teaching in Korea. In C. J. \& D. C. (Eds.), International Handbook of English Language Teaching (Vol. 15). https://doi.org/10.1007/978-0-387-46301-8_7.

Solano, L., Cabrera, P., Ulehlova, E., \& Espinoza, V. (2017). Exploring The Use Of Educational Technology In Efl Teaching : A Case Study Of Primary Education In The South Region Of Ecuador. Teaching English with Technology, 17(2), 77-86. http://www.tewtjournal.org. http://www.tewtjournal.org

Tan, C. (2019). Sense making and sense giving in schooling reform : South Korea and China Sense making and sense giving in schooling reform : South Korea. Globalisation, Societies and Education, 17(4), 536-547. https://doi.org/10.1080/14767724.2019.1567302.

Toro, L. V, Pinza, E. I., Vargas, A. B., Zúñiga, A., Paredes, F. M., \& Espinoza, F. O. (2019). Teachers and students ' perceptions of teaching and learning English in small classes : a case of Ecuador. TOJET: The Turkish Online Journal of Educational Technology, 18(1), 95-104. 
Vasquez-Martinez, C.-R., González-Gonzalez, F., Flores, F., Cardona-T, J.G., González, I., Espino, P., Olaguez, E., Rendon, H., Chavoya, J., Valdes-Perea, A.-L., Álvarez, M.-I., Torres-Mata, J., BetancourtNuñez, E.-M., Rodríguez-Ramírez, S.-E., Álvarez-Gómez, S.-E.L., Álvarez, M.-I., Torres-Mata, J., Betancourt-Nuñez, E.-M., RodríguezRamírez, S.-E., Álvarez-Gómez, M., Cabral-Araiza, J., \& Anguiano, C. (2018). Reflections on Educational Reforms in Latin America and paintings in their steps fractals. In Education in Modern Society (Vol. 16).

Viáfara, J. J. (2011). How Do EFL Student Teachers Face the Challenge of Using L2 in Public School Classrooms ? Profile Issues in Teachers ' Professional Development, 13(1), 55-74.

Villao Tomalá, D. C. (2016). Digital tools in second language learning.

Sinergias Educativas, 1(2). https://doi.org/10.37959/se.v1i2.16

Wang, L. Y., \& Lin, T. Bin. (2013). The representation of professionalism in native English- speaking teachers recruitment policies: A comparative study of Hong Kong, Japan, KoreaandTaiwan

$$
\text { EnglishTeaching, 12(3), 5-22. }
$$

https:/files.eric.ed.gov/fulltext/EJ1017167.pdf

Yang, J. (2017). A historical analysis of language policy and language ideology in the early twentieth Asia: a case of Joseon, 1910-1945. Language Policy, 16(1), 59-78. https://doi.org/10.1007/s10993-0159396-5.

Yuasa, K. (2010). English Textbooks in Japan and Korea. Pan-Pacific Association of Applied Linguistics(PAAL), 14(1), 147-158. https://eric.ed.gov/?id=EJ920509 